\title{
SPRACHLICHE STUDIEN
}

\author{
(Dritte Serie)
}

\author{
voN \\ FRIED. W. BERGMANN
}

Prof. in Strassburg.

S'TRASSBURG

DRUCK VON G. SILBERMANN.

1872 
STRASSBURG, DRUCK VON G. SILBERMANN. 